\title{
MUSLIM LIBRARIES IN HISTORY
}

\section{Nurdin Laugu}

A lecturer at Adab Faculty of the State Islamic University (UIN) Sunan Kalijaga Yogyakarta.

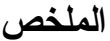

بؤكد التاريخ أن المكتبات الإسـادية قد لعبت دور ا مهما في تتمبية العلوم و الحضـارة خاصة للى المسلمبن. هناك جوانب من المكتبات الإسلادية عبر تاريخها الطويل توحي الباحثين للنظر فيها منها (1) وجود بيث الحكمـة ومجده في بغداد في القرن الثاني الهجري كما نجدها في المراجع عن فكر المكتبات الإسـالابية (r) ظهور المكتبات الإسلادية فى بد/ية تكوبن المجتمع الإسـالمي الأول منها حفظ المصساحف في المساجد و الأماكن الأخرى. ويحاول هذا البحث أن بتابع ظهور المكتبات الإسلامية وبناء التقسبم العلمي لها ووالقضية الأولى المطروحة هـي عن أصول المكتبات الإسـاحية التاريخية التي نستطبع من خلالها أن نعرف نشأتها ولماذا توقهت نهضتها ـو القضية الثانبية هي عن الوثائق وعدد من المراجع عن المكتبات الإسالاية في المجتهع الإسـالادي وأنواعها عبر التاريخ الإسلامي مدا بصور نداذج من المكتبات الإسـالابية في العالم الإسـالامي. والقضية الأخبرة هي محاولة بلورة المكتبات الإسلادية في العالم الإسالمي.

\section{Abstrak}

Secara historis, perpustakaan Islam telah memberikan banyak kontribusi dalam sejarah perkembangan peradaban dan ilmu pengetahuan, khususnya di kalangan ummat Islam. Isu perpustakaan Islam yang sangat menarik dan babkan kontroversial dalam perjalanan sejarah Islam adalah, 
Nurdin Laugu

misalnya, eksistensi dan kejayaan perpustakaan Bayt al-Hikma di Baghdad pada abad II Hijriyyah. Selain itu, perlu dicatat bahwa fenomena semacam ini banyak ditemukan dalam literatur-literatur wacana perpustakaan Islam. Isu yang menarik pula adalab kemunculan perpustakaan Muslim telah berbasis dari awal pembentukan masyarakat Islam, misalnya penyediaan koleksi-koleksi al-Quran di masjid dan mushalla serta tempat ibadah lainnya. Tulisan ini mencoba menelusuri dan membangun tipologi perpustakaan Muslim dan menjajaki isu-isu kemunculan dan perkembangan sampai stagnasinya. Wacana pertama yang disodorkan adalah asal-usul perpustakaan Islam, yang bertujuan untuk melihat sejaub mana perpustakaan mengalami perkembangan dan kemajuan dalam masyarakat Islam. Pembahasan selanjutnya mengenai temuan-temuan dari beragam literatur tentang perpustakaan di kalangan masyarakat Islam untuk membangun tipologi perpustakaan Muslim yang dianggap merepresentasikan jenis-jenis perpustakaan Muslim dalam sejarah perkembangan Islam. Terakbir adalah wacana yang mencoba untuk. mengeksplorasi proses stagnasi dan babkan keruntuban perpustakaan Islam.

Keywords: Muslim library, bayt al-ḩikma, and typology of library.

\section{A. Introduction}

From the historical perspective, Islamic libraries display a prestigious development that parallels advances in intellectual activity in the Muslim world, such as in the era of al-Ma'mūn. It seems that this occurred over a long period, starting from the beginnings of the transitional period, when Arab Muslims began to adapt the Hellenistic and Syrio-Persian civilization. This great progress continued until the beginnings of the medieval period, according to Hodgson's thesis on the historical periods of Islamic society. Disregarding the limited periods of brilliant evident in the development of Muslim libraries, this study is going to explore the existence of such libraries over the whole span of Islamic history, including the era of stagnation of Muslim communities. Therefore, it is important to approach this topic by using Hodgson's thesis mentioned above, because in this way we can arrive at a clear picture of the long history of Islamic culture from the early 
formation of Muslim society to the modern era.

One of the interesting phenomena addressed in this study is the scientific development occurring during different periods within Muslim communities, and particularly among Islamic scholars. Thus, this research will explore a number of Muslim scholars, for the reason that they possessed private libraries or had a connection with the rulers or ruling families who were interested in the development of libraries. This is not the only point of interest, for the very books themselves that were circulated in such Islamic institutions as madrasas and mosques also constitute an important issue. It is in connection with this that Makdisi, in his book The Rise of Colleges, quotes the opinion of Eche to the effect that there are at least seven terms, such as Bayt al-Hikma and Där al-Kutub, which have consistently been used for describing libraries in the historical contexts of the Muslim world. ${ }^{1}$

Nevertheless, the focus of this study includes all types of Muslim libraries, which therefore lead us to use a typological approach. It is hoped that by this method we will be able to reveal the variables connected and interconnected within the natures of the libraries we are going to investigate, so that all types can be easily identified. The main thing to be discussed is related to the library development in Islamic society, which consists of three points in issue, namely; (1) The extent to which the origins and the development of the Muslim libraries that we are going to explore can be traced in the efforts and behaviours of Muslims concerning the emergence of libraries among them, from the rulers, subjects as well as society as a whole. (2) In this part will be discussed the typology of Muslim libraries. Because this is the main issue in this discussion, the analysis of this point is therefore more detailed and longer than the other sections. The writer is trying

${ }^{1}$ Such terminology gives clear evidence of the existence of the Muslim libraries. Three words from this lexicon indicate locales, namely: Bayt (room), Khižanat (closet), and $\overline{\bar{a}}$ (house) and the three others are about the contents, namely Hikma (wisdom), I Im (knowledge), and Kutub (books). According to Eche, the combination of the six words produces seven terms, which all mean a library, as can be seen from the following: Bayt al-Hikema, Khizānat al-Hikema, Där al-Hikema, Där al-Tlm, Där al-Kutub, Khizānat alKutub and Bayt al-Kutub; see Richardson, The Beginnings of Libraries, (London: Archon Books, 1963), p. 14-21. 
to explore as deeply as possible the existence of different types of Muslim libraries based on a number of sources in books and journals. The typology of libraries is based only on the ownership or the control by a person, not on whether or not the services are open to public. Consequently, public and special types will not be found in this typology. (3) Other related issues, including some notes on the destruction of Muslim libraries.

Based on the typological approach, there are five types which are considered to be representative of Muslim libraries in the whole span of the history of the Muslim world. First, mosque libraries are proposed as the first type for the reason that mosques are believed to be the oldest Muslim institution in which collections are located. This type is followed by the libraries of rulers or ruling families. These are also assumed to be amongst the oldest Muslim libraries. This type includes every library under the supervision of the rulers (caliphs, viziers and katib) or ruling family, such as princes. Then, the collections provided in the madrasas (schools) are termed here madrasa libraries. This type started when Islamic education moved from the mosques to madrasas. Fourth are the libraries of scholars. This refers to the private collections of Muslim scholars. Last are the university libraries, which are believed to be the most recent Muslim libraries in Islamic society.

\section{B. The Origins of Muslim Libraries}

It is assumed that since the formation of Islamic society the stimulation towards the emergence of Muslim libraries has existed. An indication that can throw light on the beginnings of Muslim libraries is seen in the collections of students' notes and little treatises which could be described as letters or books, and which were placed either in mosques or kept by the students as private collections, or could also have been found in the collections of the Caliphs. ${ }^{2}$ However, Hamāda argues that there is no clear evidence about the initial emergence of Muslim libraries, particularly the mosque libraries, but nevertheless

${ }^{2}$ Mackensen, "Arabic Books and Libraries in the Umaiyad Period" in The American Journal of Semitic Languages and Literatures, Vol. 52, October 1935-July 1936, p. 59 via Sibai, Mosque Libraries: An Historical Study, (London: Mansell Publishing Limited, 1987), p. 48. 
this is believed to have started in the early beginnings of Islam, in which the Muslims had stored the Qur'an and other books on Islam in the mosques. However, he furthers his elaboration by stating that the central task in the exploration of the existence of a library is to pay attention to the early period during which the mosque was established as a place for learning because, according to him, there is no learning without books, and so the first libraries in Muslim communities were the libraries of mosques. ${ }^{3}$

With regard to this issue, the name of Khālid b. Yazid (d. 85 A.H.) is often connected with the earliest Muslim collection of books. Khālid is said to have devoted his life to the study of Greek sciences, particularly alchemy and medicine. According to Ibn al-Nadim, Khālid employed a certain Stefanus to translate books on these subjects for him and for the supply of his library. ${ }^{4}$ It is reported that in the late $7^{\text {th }}$ century and the $1^{\text {st }}$ half of the $8^{\text {th }}$ century, caliphs and princes of the Umayyad dynasty gave considerable attention to books and libraries by which they collected, copied, and translated many Greek manuscripts into Arabic. ${ }^{5}$ Both literary activities and the introduction of paper had great impacts on the intellectual activity of the Islamic peoples. $^{6}$

The love for learning and education of the early Muslims required the establishment of libraries whereby in the second century A.H., hundreds and even thousands of libraries, whether or not their services were open to public, were established all over the Muslim empire. ${ }^{7}$ It is worthwhile attempting to explore the evidence of libraries alongside the societies in which they existed, for these became rather more sophisticated after the transitional first century. Thus, such cases can throw light on the diffusion of libraries as follows "Firstly, Arab-Islamic

${ }^{3} \mathrm{Hamāda}$, Al-Maktabat fìll Isläm: Nash'atubā wa Tatanwurubā wa Masāìrubā, (Bayrūt: Mu'assasat al-Risāla, 1981), p. 82 and see also Diyāb, Al-Kutub wa'l Maktaba fíl Andalus, (al-Qāhira: Dār Qibā' li'l-Ṭibā'a wa'l-Nashr wa'l-Tawzì', 1998), p. 100.

${ }^{4}$ Shalaby, History of Muslim Education, (Beirut: Dār al-Kashshāf, 1954), p. 87-88.

${ }^{5}$ Meho, Libraries and Information in the Arab World: An Annotated Bibliography, (London: Greenwood Press, 1999), p. 1.

'Mackensen, “Arabic,” Vol. 54 (October 1937: 41-61). p. 60.

${ }^{7}$ Diwan, "Muslim Contribution to Libraries During the Medieval Times" in Islam and the Modern Age: A Quarterly Journal, Vol. 9 No. 2 (May 1978: 19-34), p. 20. 
culture became more sophisticated in large part by accelerating its adaptation to Hellenistic and Syrio-Persian institutions, acquiring culture traits worldwide (i.e., from India and China too) as it grew increasingly cosmopolitan and as it extended its trade routes. Secondly, the impact of the introduction of paper from China (late eight century) on Arab society's book-making and book-collecting activities was as profound as that of printing on those of Europe later. Among the internal adjustments to the paper revolution was the creation of larger and more complex libraries. Finally, some scholars speculate that two of the three great Arab research libraries (those in Baghdad and Cairo) were deliberate attempts to recreate, on the basis of surviving written accounts, Alexandria's ancient Museion and Serapium."

In a comparative sense, Muslim libraries are similar to those of Jews and Christians, which began as collections of religious books. Passing through several periods, Synagogue, Church and Monastic libraries transformed into public colleges and then universities, which were attached to libraries. The same thing happened with the mosque libraries of the early Muslim period, which developed into the madrasa and university libraries of the middle age. ${ }^{9}$ Besides this, mosque libraries, like western church and synagogue libraries, were established to serve the religious needs of the immediate congregation. ${ }^{10}$ The history of the libraries of the Syrian monasteries contains many illuminating parallels to that of Muslim libraries, which had served as their models, with papyrus or parchment scrolls or codices being stored in closets or wall niches. ${ }^{11}$ These phenomena lead us to the realization that Eastern libraries, whether Christian or Muslim, were very similar. ${ }^{12}$

${ }^{8}$ Green, "The History of Libraries in the Arab World: A Diffusionist Model" in Libraries and Culture, 23 (4), (Fall 1988: 454-473), p. 457.

${ }^{9}$ Imamuddin, Some Leading Libraries of the World, (Dhaka: Islamic Foundation, 1983), p. 21.

${ }^{10}$ Harvey, "Tehran Mosque Libraries and a Comparison with American Christian Church Libraries” in International Library Review, Vol. 13 (1981: 385-395), p. 386.

${ }^{11}$ Green, "The History," p. 456.

${ }^{12}$ Mackensen, "Background of the History of Muslim Libraries" in The American Journal of Semitic Languages and Literatures, Vol. 52 (October 1935-July 1936: 22-33, 104110), p. 109. 
The idea of libraries not purely as storehouses of books but as centres of culture and learning was taken over along with foreign literature and developed into something quite characteristic and individual. The Arabs saw the collections of books in Christian monasteries and churches, whether in the houses of scholars or in the palaces of enlightened rulers of Byzantium and Persia, and heard or read of the great Greek libraries and academies. ${ }^{13}$ It is even said that the libraries of the Christians in the fourth century in Rome numbered twenty-eight public libraries. ${ }^{14}$ Therefore, the Arab-Muslims learnt magnificent things about libraries, whether from the Roman Christians or from the Greek libraries, particularly that of Alexandria. Besides, there were also the library of Antiochus III at Pergamum and the imperial collection of Constantine, which may well have passed on to them. These libraries were located in places at which early Muslim bibliophiles gathered many of their books on philosophy and ancient sciences. ${ }^{15}$

Learning from this time, Arab Muslims had great models for the development of their own libraries. As a result, from the eighth to the tenth century there was a network of libraries, which included private and public collections covering the territory of Muslim regions from Shiraz in Persia in the East to Cordova and Toledo in the heart of Spain in the West, as well as Baghdad which in the time of its glory had thirty-six libraries. ${ }^{16}$ We must also mention India, where the first Mughal library was established in 1526. Humayun, the son of the founder of the Mughal Empire, continued his father's tradition. He shifted the imperial library to Agra. He himself was a scholar and bibliophile and was so fond of reading that during his travels he carried

${ }^{13}$ Bashiruddin, "The Fate of Sectarian Libraries in Medieval Islam" in Libri: International Library Review, Vol. 17 (1967: 149-162), p. 154.

${ }^{14}$ Bukhsh, "The Islamic Libraries" in The Nineteenth Century and After, Vol. 52 (July-December 1902: 125-139), p. 125.

${ }^{15}$ Mackensen, "Background," p. 28 and see also Khalifa, Maktabat al-Iskandariyyat

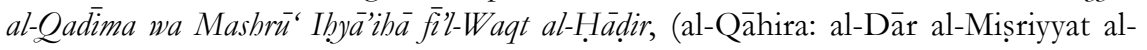
Lubnāniyya, 2002).

${ }^{16}$ Bashiruddin, “The Fate,” p. 154. 
a selected library with him. ${ }^{17}$ In North Africa, Cairo had some of the finest collections under the Fatimid Caliphate. Apart from the royal library, the city had at least four great private libraries. Arabic Spain had no less than seventy libraries. ${ }^{18}$ It appears that the most prestigious libraries of the Muslim communities were often founded by learned individuals through the philanthropy of scholars, aristocrats, and caliphs. Under this patronage, many mosques flourished and developed enviable libraries accessible to scholars from all over the Islamic world. ${ }^{19}$

Oral transmission still played a fundamental role, but a real start had been made in the preservation of literature by means of writing. Nevertheless, one finds at the same time serious attempts to preserve the old and authentic creative activity. The early books were merely collections of students' notes and little treatises in the form of letters or more formal books gathered together. The time when such materials were felt to be worth keeping can legitimately be considered as the beginning of Muslim libraries. One may therefore speak of the libraries, in spite of few, of the caliphs and private individuals. The preservation of source materials is as much the proper function of a library as is the preservation of formally published books. ${ }^{20}$ Later, professors of colleges quite frequently gave their own works and private libraries to their respective institutions. Books are often mentioned among the waqf or pious bequests made in perpetuity by scholars and men of wealth ${ }^{21}$ as well as a certain management of the expenditure for the libraries is provided for the salaries of the professors, Islamic scholars, collections, reservation, papers, etc. ${ }^{22}$

The emergence of libraries in Andalusia is said to have been connected with the intellectual and ideological movements of the time.

${ }^{17}$ Khurshid, "Growth of Libraries in India" in International Library Review, 4 (1972: 21-65), p. 23.

${ }^{18}$ Bashiruddin, "The Fate," p. 154.

${ }^{19}$ Ben-Aicha, "Mosques as Libraries in Islamic Civilization, 700-1400 A.D." in The Journal of Library History, Vol. 21, No. 2 (Spring 1986: 253-260), p. 255-256.

${ }^{20}$ Mackensen, "Arabic," Vol. 54 (October 1937: 41-61), p. 59.

${ }^{21}$ Mackensen, "Four Great Libraries of Medieval Baghdad" in The Library Quarterly, Vol. 2, No. 3 (July 1932: 279-299), p. 280.

${ }^{22}$ Benjelloun-Laroui, Les Bibliotheques au Maroc, Paris: G.-P. Maisonneuve et Larose, 1990, p. 21. 
The libraries serve as indicators of these intellectual and ideological movements. ${ }^{23}$ Four factors that relate to the development of libraries in Andalusia may be mentioned here. First, the love of collecting books had become popular amongst the people of Andalusia, which in turn led to the blossoming of writing. This time was a favourable period for Islam in the West. Second, the love of books among the people of Cordova had boosted the emergence of libraries. Third, the development of different libraries was mostly motivated by different individual interests. Lastly, the love of books is also said to have initiated the spread of education and eradicated illiteracy among the Andalusians. ${ }^{24}$ Apart from the four already mentioned, there were a number of ways to develop Muslim libraries, firstly through the purchasing of books and manuscripts, which were important for the religion of the caliphs. Another important source of development is the copyists who were hired to produce copies of books and manuscripts. The other significant source is the people who were responsible for hunting for endowments (waqf) for libraries, or the scholars or the caliphs and their viziers who donated their books or financial contributions to the development of the collections of the libraries. ${ }^{25}$

\section{Typology of Muslim Libraries}

The development of Islamic libraries has become a dispute among historians concerned with the early sources of Islamic history. This particularly concerns the sources, which seem to contain a variety of legends about libraries within the Muslim community. In order to observe this phenomenon through an academic perspective, we may turn to an interesting work written by Van Koningsveld concerning the stories around the Bayt al-Hikma. Van Konigsveld's work was basically devoted to developing a critical account of stories found in the different sources relating the development of the collection of the Bayt al-Hikma. One may find obviously contradictory stories on the

${ }^{23}$ Diyāb, Al-Kutub wa'-Maktaba fîl'-Andalus, (al-Qāhira: Dār Qibā' li'l-Ṭibā'a wa'lNashr wa'l-Tawzi', 1998), p. 93.

${ }^{24}$ Ibid., p. 97.

${ }^{25}$ Ibid., p. 111-112. 
topic of the acquisition of Greek manuscripts, namely the manuscripts brought from the Eastern Roman empire in the time of al-Ma'mūn. By contrast, some historians assume that all Greek manuscripts and books of Alexandria and Ctesiphon had been burnt in the time of Umar. Given the fact that there was no consensus on the nature of the Islamic library Bayt al-Hikma, ${ }^{26}$ scholars still maintained an open debate. This analysis becomes increasingly interesting when it is read alongside other writings questioning the accounts of the destruction of the Alexandrian library in the reign of 'Umar. ${ }^{27}$ Regardless of the wide range of approaches which may result in contradictory versions, the fact remains that historical accounts of the existence of Muslim libraries have for long been found intertwined within the history of Islamic society.

In some instances, a systematic historical approach has been adopted, particularly by Green, who primarily referred to Marshall Hodgson's thesis on the framework of Arab history in general, and that of Islamic libraries in particular. The strong emphasis of this investigation is seen in its culture-oriented classification. He proposes an initial period, namely the period of traditional Arab culture until the mid-seventh century A.D., followed by a second phase in the form of a transitional century during which Arab-Islamic culture adapted to the Hellenistic and Syrio-Persian civilization up to the mid-eighth century. A third period can be identified, namely the genesis of the classical period, which is known as the cosmopolitan period of ArabIslamic culture occurring up to the mid-thirteenth century. The fourth period is known as the medieval time, which began from the midthirteenth century to the late sixteenth century. The final phase is characterised by economic-cultural inertia from the late sixteenth to

${ }^{26}$ Van Koningsveld, "Naskah-Naskah Yunani Tentang Bait al-Hikmah dan Kebijakan Beragama Khalifah al-Makmun" in Herman Leonard Beck \& Nico Kaptein (eds.), Studi Belanda Kontemporer Tentang Islam: Lima Contoh, (Jakarta: INIS, 1993), p. 5760 or see also Van Koningsveld, "Greek Manuscripts in the Early Abbasid Empire: Fiction and Facts about Their Origin, Translation and Destruction" in Bibliotheca Orientalis, Vol. 55 (Mey-August 1998: 345-372).

${ }^{27}$ Rau, "Did Omar Destroy the Alexandrian Library?" in The Nineteenth Century, 36 (July-December 1894): 555-571, 560-561. 
the eighteenth century. ${ }^{28}$ Using Hodgson's view as a historical landscape, Green develops his line of investigation by arguing that the history of Muslim libraries showed maturation in the second and third phases. This is indicated by the emergence of different kinds of libraries such as mosque and state libraries during these phases. ${ }^{29}$

With regard to the current study, we will concentrate basically on the typology and development of libraries in the Muslim world. Although Green's view highlighted the second and third of Hodgson's phases as the critical periods during which Islamic libraries flourished, this exploration will not be limited to those two phases, but will also explore the possibility of the existence of libraries from the early formation of Islamic society until the modern time. In doing so, the basic discourse will be focused on the typology ${ }^{30}$ concerning the emergence of the different libraries among the Muslim communities within the whole span of Islamic history.

\section{Mosque Libraries}

It is believed that the growth of mosque libraries has been in evidence since the beginning of Islamic development, and was indicated by the transitional century of Arab-Islamic culture in which it adjusted to Hellenistic and Syrio-Persian civilization. The existence of the libraries is mostly premised on the assumption that Muslims had been highly motivated to study and understand their religion. Such an environment encouraged the asking of many questions, and in turn resulted in many knowledge groups or circles which studied the teachings of Islam in mosques. Since the commencement of intensive study of Muslim affairs, Medina became an important centre of Islamic intellectual life. ${ }^{31}$ It is in this connection that the mosque accompanied

${ }^{28}$ Green, "The History," p. 455.

${ }^{29}$ Ibid., p. 455-456.

${ }^{30}$ Typology is made based upon consideration of the ownership or control of the intended libraries instead of its services. As a result, the use of the terms "public or special libraries" is avoided because almost all kinds of Islamic libraries in history may have been open to public. Based on this approach, the ambiguity of the typology can be reduced as much as possible.

${ }^{31}$ Spies-Aligarh, "Die Bibliotheken des Hidschas" in Zeitschrift der Deutschen Morgenl ndischen Gesellschaft, Vol. 90 (1936: 83-120), p. 91-92. 
by a library became a very cheap high school, as the groups of students sat on the floor, mostly in the same big hall, and the library usually became an attraction to students who were in the mosque. ${ }^{32}$

Another location, known as the second caliphate of the Umayyads, was in Spain, where the Muslims founded many mosques, some of which contained books that were used by people who did not have private collections. One of the biggest and most influential examples was the Grand Mosque of Cordova, which was founded in $170 / 786$ by the Umayyad prince, 'Abd al-Rahmān. It is recorded that inside this great mosque were stored a large number of books and volumes of the Qur'an. In line with the classical age of cosmopolitan Arab-Islamic culture occurring from the Mid-Eighth to Mid-Thirteenth century, the cosmopolitan activity of the time is indicated by an increase in endowment activities, which stimulated the development of mosque libraries. It is of interest to note that one of the benefactors who donated all his books to the grand mosque of Seville was the scholar Ibn Marwān al-Bajpi. ${ }^{33}$ It is also significant to mention that the famous mosque libraries were in the city of Cordova and Toledo. ${ }^{34}$

During this classical age, the establishment of the Fattimid caliphate in Egypt became an important epoch in which the Djämi' alAzhār was founded by the caliph Mu'izz (358-65/968-75). ${ }^{35}$ Just after the building of the al-Azhār, the successor of the caliph Mu'izz, al'Ażz Billāh (reigned 365/975-386/996) set up a great library, in 988 A.D., which was attached to the Djāmi' al-Azhār, ${ }^{36}$ and which was the first library in Cairo. ${ }^{37}$ During the time of this caliph, the al-Azhār mosque library contained 200,000 volumes, and was later connected

${ }^{32}$ Pedersen, "Some Aspects of the History of the Madrasa" in Islamic Culture, Vol. 3 (1929: 525-537), p. 529 and see also Nashshār, Tärikh al-Makatabät $\bar{f}$ Misra: al-'Assr al-Mamlūkì, (Cairo: al-Dār al-Miṣriyyat al-Lubnāniyya, 1993), p. 80-87.

${ }^{33}$ Sibai, Mosque, p. 55.

${ }^{34}$ Diyāb, Al-Kutub, p. 101.

${ }^{35}$ Ben-Aicha, "Mosques," p. 257.

${ }^{36}$ Pinto, "The Libraries," p. 225.

${ }^{37}$ Merlet, Shukrieh R. "Islamic Libraries of the Middle East" in Libri, Vol. 39, No. 2 (1989: 127-140), p. 133, and see also Sāqāqi, Yạ̣āa Mạ̣mkd, Al-Waqf wa Bunyat al-Maktaba al-'A rabiyya: Istibtān li'-Mawrüth al-Thaqā̄î̀, (al-Riyāẹ: Al-Mamlakat al-'Arabiyya al-Su'üdiyya, 1988), p. 67. 
to an educational institution. ${ }^{38}$

Further accounts are those recorded by Ibn Khallikan at the time when Sultan Salāh al-Dinn entered Aleppo in the Year 579 (A.D. 1183). Al-Mas'údi (al-Bandahị) went down to the great mosque of that city, and having installed himself in the library of books given as a wagf to that establishment, selected a number of them and took them away without meeting the slightest opposition. ${ }^{39}$ The other account of Ibn Khallikan concerning mosque libraries is his statement that in Damascus he observed the library of Ashrafiyya to contain the diwan (collected poetical works) of Ibn Abi al-Sakr, which is preserved in the turba or mausoleum erected over the tomb of al-Mālik al-Ashraf. It is situated to the north of the building erected as an addition to the Great Mosque, or al-Djami' al-Kabir, which is called al-Kallasa. ${ }^{40}$

The next period we have identified as the medieval era of regional Arab-Islamic societies, which ran from the mid-thirteenth to the late sixteenth century. At this time, the Qarawiyyin Mosque in Fez contained three separate libraries. The libraries were not located within the mosque, but in an annex building. The first and most prestigious was the $A b \bar{u}$ Tnān Library, also known as the Tlmiyya Library in 750/1349, the name of which was derived from the Merinid Sultan Abu 'Inān Făris. The second one is the $A b \bar{u}$ Yusuf library at the Qarawiyyin, which was equally nourished and supported. The third Qarawiyyin library was of considerable importance, and was founded around the year 996/1587 by the scholar king, Aḥmad al-Manșūr al-Dhahabi of the Sadiyya dynasty. ${ }^{41}$

It is recorded that the richness of these mosque libraries attracted European scholars in search of ancient works to Fez. But in the 19th century it had fallen into a pitiable state of abandonment, dilapidation and pillage. The supervision of the library was in principle incumbent on the nakkib of the university's pious foundations, but he shifted the

${ }^{38}$ Imamuddin, Some, p. 34.

${ }^{39}$ Ibn Khallikan, Biographical Dictionary, transl. from the Arabic by Mac Guckin de Slane, Vol. 3, Paris: Oriental Translation Fund, 1871, p. 100.

${ }^{40}$ Ibid., p. 148.

${ }^{41}$ Sibai, Mosque, p. 55-56 and see also "al-Karawiyyin" in The Encyclopaedia of Islam, WebCD Edition, (Leiden: Brill Academic Publishers, 2003). 
responsibility onto a student agreed upon by higher authority. No catalogue or register of loans has been discovered, as was the case in Marrākash at the Library of the Mosque of Ibn Yüsuf. Many borrowers must have neglected to return the works, to such an extent that at the beginning of the 20th century the number was estimated at no more than 1600 manuscripts and 400 printed books. Some are very valuable or very rare, in particular the 5th volume of the kitäb al-Tbär of Ibn Khaldūn, with a dedication in the famous historian's own hand. There are also volumes there that are marked with records reporting their donation by certain Moroccan princes. The most ancient manuscripts date back a thousand years, and most of them were the result of gifts. ${ }^{42}$

\section{Libraries of Rulers or Ruling Families}

The critical analysis concerning the history of the Arabs schematised by Green reveals that the Arab interest in Hellenistic science started at the beginning of the Umayyad caliphate, as can be seen from the scholarly activities of Khālid b. Yazid (d. 685) ${ }^{43}$ as well as those of 'Abd al-Mālik b. Marwān (685-705 A.D) who engaged scholars for the writing of works on various arts for his royal library, and which was known to have preserved the exegesis of the Quran written by Said b. Jubayr. ${ }^{44}$ This scientific effort resulted in the establishment of the Umayyad palace library in Damascus ca. 700. Although little is known of its organization, this library allegedly consisted of commissioned translations from Greek and Coptic texts, Christian scholars having served as the translators. Soon after, these intellectual activities were continued by the caliph 'Umar b. 'Abd al'Aziz (717-720 A.D.). According to some writers, however, the existence of libraries such as these in a location central to Arab tradition seems to represent a case of borrowing and adaptation rather than one of independent invention. ${ }^{45}$

As we enter the classical era, we observe the caliph Hārūn alRashid (786 A.D.) as a maker of remarkable improvements in the field

\footnotetext{
${ }^{42}$ See "al-Karawiyyin" in The Encyclopaedia of Islam.

${ }^{43}$ Green, "The History," p. 457.

${ }^{44}$ Imamuddin, Some, p. 22.

${ }^{45}$ Green, "The History," p. 457.
} 
of libraries. ${ }^{46}$ His library was attached to Bayt al-Hikma, ${ }^{47}$ which is sometimes described as the most famous and outstanding public library in Baghdad. ${ }^{48}$ Based on the opinion of Sa`id al-Dārimi, KhaTifa reveals that the library of Bayt al-Hikma originated from the library of $\mathrm{Mu}$ a'wiya b. Abi Sufyān, and then moved to Khâlid b. Yażid b. Mu'āwiya. It is said to have been handed down from one caliph to another up to the time of Hārūn al-Rashid and al-Ma'mūn, who are known as the most prominent founders of the Bayt al-Hikma. In this time, according to historians, the Bayt al-Hikma was transformed from a royal library to become a state library and was given the status of an academy, ${ }^{49}$ which is considered to be the first institution of higher scientific studies among the Arabs and is believed to have provided a combination of services including its library, academy, translation bureau, laboratories, a transcription service and observatories. ${ }^{50}$

The Bayt al-Hikma was enriched with manuscripts from the Byzantine Empire, ${ }^{51}$ and it is reported that caliph al-Ma'mūn entered into relations with the emperors of Constantinople who sent him "works by Plato, Aristotle, Hippocrates, Galen, Euclid, Ptolemy and others still." ${ }^{12}$ Al-Ma'mūn engaged Ya'qūb b. Ishāq al-Kindi, who wrote 282 books and memoirs on medicine, philosophy, music, etc. for the translating of Aristotle's books into Arabic. Rare books were collected from other places such as Egypt, Syria, Iran, and India. Hadjdjaj b. alBatring and the principle of the college, Salām or Salma by name, were

\footnotetext{
${ }^{46}$ Diwan, "Muslim," p. 21.

${ }^{47}$ Pinto, "The Libraries," p. 223.

${ }^{48}$ Merlet, "Islamic," p. 132.

${ }^{49} \mathrm{Khalifa}$, Al-Kutub wa'l-Maktaba fìl- 'Ușūr al-Wustāa, (Cairo: al-Dār al-Mișriyya alLubnāniyya, 1997), p. 282-284.

${ }^{50}$ Prince, "The Historical Context of Arabic Translation, Learning, and the Libraries of Medieval Andalusia" in Library History, Vol. 18 (July 2002: 73-87), p. 81. and see also Mackensen, "Four Great Libraries of Medieval Baghdad" in The Library Quarterly, Vol. 2, No. 3 (July 1932: 279-299), p. 281.

${ }^{51}$ Ibn al-Nadim, The Fibrist of al-Nadim: A Tenth-Century Survey of Muslim Culture, transl. and ed. by Bayard Dodge, Vol. I, (New York: Columbia University Press, 1970), 584-586.

${ }^{52}$ Micheau, "The Scientific Institutions in the Medieval Near East" in Encyclopedia of the History of Arabic Science, Vol. 3 (1996: 985-1007), p. 986.
} 
sent to countries of the Roman empire to collect works of their own choice. Qustā b. Lūqa went to the Greek countries in search of books. Hunayn b. Isḥāq went in search of Kitāb al-Burbān to Palestine, Egypt, and Syria and obtained only half of it in Damascus. ${ }^{53}$ Among other scholars who were engaged for the translation of different works into Arabic were three brothers, Muhammad, Ahmad and Hasan, known collectively as the Banū Mūsā. Besides them, there were also Yahyā b. Abì Manșūr, and the Christians Quștā b. Lūqā and Hunayn b. Ishāà, and the Sabian Thäbit b. Qurra. ${ }^{54}$ We can add to the afore-mentioned Yuhanna b. Masāwayh and Muḥammad b. Mūsā al-Khawarizmì, who also acted in the same way. ${ }^{55}$

In addition to that, there was also a famous one founded by the caliph al-Hakam II in Cordova, which is said to have contained no less than four hundred thousand volumes. It is confirmed by Wasserstein that al-Hakam II, an efficient ruler, was not only a bibliophile, but also a patron. ${ }^{56}$ During this time, there were in the capital many other libraries in the hands of wealthy individuals, where the studious could dive into the fathomless sea of knowledge, and bring up its inestimable pearls. Cordova was indeed, in the opinion of all authors, the city of Andalusia in which most books were to be found, and its inhabitants were renowned for their passion for forming libraries. ${ }^{57}$ The first library of importance and value in Europe was the royal library of the Umayyad in Cordova. The library of Cordova became one of the best libraries of the Muslim world during the time of 'Abd al-Rahmān II and it was added to and strengthened by 'Abd al-Raḥmān III. The beginning of

${ }^{53}$ Imamuddin, Some, p. 25 and see also Ibn al-Nadim, The Fibrist, p. 584 and Sāqāīi, $A$ l-Waqf, p. 32.

${ }^{54}$ Nicholson, A Literary History of the Arabs, London: T. Fisher Unwin, 1907, p. 359.

${ }^{55}$ Meyerhof, "On the Transmission of Greek and Indian Science to the Arabs" in Islamic Culture, Vol. 11 (1937: 18-29), p. 23-25.

${ }^{56}$ Wasserstein, The Library of al-Hakam II al-Mustansir and the Culture of Islamic Spain, Manuscripts of the Middle East (nr. ??), pp. 1-23, p. 7.

${ }^{57}$ Makkāir, The History of the Mohammedan Dynasties in Spain, Transl. and illustrated with critical notes by Pascual de Gayangos, London: Oriental Translation Fund, [Vols. 1, 1840], p. 139. 
the movement was slow but it reached its peak with the advent of Hakam II. ${ }^{58}$

Contemporary Arab scholars have stated that the library of Hakam II contained the biggest collection of all the royal libraries in the medieval world. The caliph had a great love for their systematic arrangement, classification, techniques, decorations, etc. ${ }^{59}$ In such an environment, the neo-Muslim desire for acquiring knowledge gave fresh impetus to the general predilection of the Arabs for reading. The caliphs and Amirs, especially 'Abd al-Raḥmān II and Hakam II, were interested in the collecting of books. Historians say that al-Hakam II was the most virtuous and liberal of men, and that he treated all those who came to his court with the utmost kindness. He amassed such a collection of books that it is impossible to estimate even approximately either their value or their number, and some writers state that they amounted to four hundred thousand volumes.$^{60}$ Related to this number, Wasserstein argues that al-Hakam II's library was far from being merely the private collection of a learned prince. It was a state institution. The library served as the focus of a whole nexus of cultural activities, which helped to lay the foundations for the massive explosion of literary productivity in Islamic Spain associated with the quarter of the century following al-Hakam II's death in 366/976. ${ }^{61}$

Under al-Hakim, the sixth Fạtimid caliph, a strange man in whom were mixed a great love of learning and a mad fanaticism, the assemblies of his predecessors crystallized into an academy, which, like that of al-Ma'mūn, is variously called the House of Wisdom (Bayt al-Hikma) or Abode of Science (Där al-'Tlm). This institution became at once the centre of Ismāín $\bar{i}$ propaganda, which reflected the intellectual and religious interests and ambitions of the heretical Fạtimid caliphs and

${ }^{58}$ Imamuddin, Some, 44-45.

${ }^{59}$ Diwan, "Muslim," p. 27.

${ }^{60}$ Makkāīi, The History, Vol. 2., p. 169 and Prince, “The Historical,” p. 80-82 and Kohlberg, A Medieval Muslim Scholar at Work: Ibn Ṭäwis and His Library, (Leiden: E.J. Brill, 1992), p. 72.

${ }^{61}$ Wasserstein, The Library, p. 8-9 and see also Bashiruddin, “The Fate,” p. 160. 
also became a school of science and literature, ${ }^{62}$ which imparted free education and supported teachers, scholars and students with endowment. ${ }^{63}$ To its library the caliph transferred a large quantity of valuable books from the royal collections. Running the services and all activities, it employed a sizable staff of librarians, copyists, and binders in its scriptorium. ${ }^{64}$

In the medieval era of Arab-Islamic society, it is also interesting to see an example of a library of a ruling elite established in the Delhi Sultanate, the establishment of which was a result of the literary and educational activities of the period. As a consequence, Delhi became the intellectual competitor of the famous university city of central Asia, Bukhāra. Sultān Jalāluddin Khiljị (1290) was himself a poet and patronized learning and scholarship, and like other princes, there was no book written up to his time in any branch of science of which he did not have a copy. ${ }^{65}$ He established the imperial library and regarded its librarian so highly that he conferred upon him the honour of wearing white robes which the members of the imperial house and nobles of the highest order alone could wear. ${ }^{66}$ The library was taken care of by a superintendent, a librarian and an inspector chosen from the most trustworthy people in the country. The library consists of one long vaulted room, annexed to which there were store-rooms. The prince had made scaffoldings along the large room and the store chambers, about the height of a man, three yards wide, of decorated wood. There are also catalogues in which all the titles of the books are entered. ${ }^{67}$

\section{Madrasa Libraries}

The emergence of madrasa (school) libraries commenced in the classical era of Arab-Islamic society, and was an indication of the

${ }^{62}$ Mackensen, "Background," Vol. 52, p. 23 and see also Bashiruddin, “The Fate," p. 158.

${ }^{63}$ Imamuddin, Some, p. 34.

${ }^{64}$ Nakosteen, History of Islamic Origins of Western Education A.D. 800-1350: With an Introduction to Medieval Muslim Education, (Colorado: University of Colorado Press, 1964), p. 71 and see also Mackensen, "Background," Vol. 52, p. 23.

${ }^{65}$ Khurshid, "Growth,” p. 22 and see also Prince, “The Historical,” p. 82.

${ }^{66}$ Ibid., p. 22.

${ }^{67}$ Prince, "The Historical," p. 82. 
process of Islamic learning outside mosques. ${ }^{68}$ This topic will commence with the library of the Madrasa Nizamiyya that leads us to two conflicting opinions, of which one displays the inclination of some Arabic writers to argue that the Madrasa Nizamizya was the first school devoted especially to theological and related studies. As a result, some Western writers have followed this and stated that before the founding of the Nizämiyya there were no academies or colleges in Muslim lands. The other opinion belonging to al-Maqriziz and al-Suyüti, and challenges the above argument by saying that there were madrasas in existence before the time of the Nizamizya, namely the House of Wisdom founded by al-Ma'mūn and Sābūr Ibn Ardashir in Baghdad, and that of the Fạtimid caliph in Cairo. ${ }^{69}$

Turning aside from these contradicting opinions, the important thing for us is to explore the issue of the existence of the library of the Madrasa Nizămiyya, which was founded in 457/1064 by Nizām alMuluk, ${ }^{70}$ Abū 'ATi al-Hasan b. 'Ali b. Ishạa qu al-Ṭūsi (b. 408/1018) in Baghdad. ${ }^{71}$ With regard to this issue, it is critical to connect with Hodgson's thesis on the framework of Arab-Islamic history revealing that this third typology commenced in the second phase, that is in the classical age of cosmopolitan Arab-Islamic society. In such circumstances, Ibn Battuta as well as other scholars like the Persian historian, Hamd Allāh and the Egyptian historian, Ibn al-Furāt revealed broad knowledge of the Madrasa Nizămiyya library. It is noted that Niz̄am al-Muluk gave his books to the madrasa, and that is why it bore his name. ${ }^{72}$ This library had magnificent collections, which were mostly bequeathed through waqf and gifts. ${ }^{73}$ It is noted that a number of scholars were appointed to be in charge in the daily activities of the library. Among them were al-Qāội Abū Yūsuf Ya'qūb al-Isfarā’inì (d. 498 A.H.), Muhammad b. Ahmad al-Abiwardi, the famous poet who occupied the post at the death of al-Isfarā'ini (d. 508 A.H.), Yahya b.

\footnotetext{
${ }^{68}$ Shalaby, History, p. 55.

${ }^{69}$ Mackensen, "Four," p. 295.

${ }^{70}$ Pinto, “The Libraries," p. 224 and see also Meho, Libraries, p. 2.

${ }^{71}$ Khalifa, Al-Kutub, p. 328-329.

${ }^{72}$ Merlet, "Islamic," p. 136 and see also Nakosteen, History, p. 69.

${ }^{73}$ Mackensen, “Four," p. 294 and see also Pedersen, “Some," p. 534.
} 
'Ali the son of al-Khātib al-Tabrizī who was, too, a professor of literature in al-Nizāamiyya School (d. 502 A.H.), 'ATi b. Aḥmad b. Bakrì (d. 575 A.H.) the notable writer and calligrapher ${ }^{74}$ as well as al-Ghazāil and Ibn Jābir. ${ }^{75}$

In the same classical age, the library of Madrasa Mustansiriyya was founded by the caliph al-Mustansir, in which the library was placed in one important big hall of the building of the madrasa. It is reported that the famous name of this library encouraged people to come to it and became familiar with the collection. ${ }^{76}$ It was founded in $625 / 1226$ $\left(631 / 1233^{77}\right)$ by the caliph al-Mustanșir Billāh. Rare and valuable books laden on 160 camels (130 loads of books ${ }^{78}$ ) were transferred to it from the royal library. This institution is one of the many institutions founded by Mustanșir, but it topped the list. A hospital and a library were attached to it. Ibn Battūta gives a detailed description of the building and the function of the seminary. ${ }^{79}$ In this library, al-Maqrizi relates, there was a copy of the Kitāb al-Yâsah which contained the edicts issued by Genghis Khan to his people. It possessed, too, a copy of Tärikh Baghdäd in 14 volumes written by the author himself. ${ }^{80}$

The library of Madrasa al-Fadiliyya, which was in general terms the most famous madrasa library in its time was developed by al-Qạ̣̄i

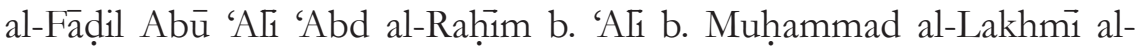
Bisānì al-'Asqalāni (529/1135-596/1200) in Cairo. It is reported that al-Fā dil was a vizier of Șalāh al-Din al-Ayyūbi, who at the time of the fall of the Fạtimid caliphate to al-Ayyūbi was involved in the affairs of the Fatimid library, some of the collections of which were moved to his madrasa library. With this being the case, he was able to develop his madrasa together with its library to the point where it achieved

${ }^{74}$ Shalaby, History, p. 86-87.

${ }^{75}$ Khalifa, Al-Kutub, p. 328-329.

${ }^{76}$ Ibid., p. 332-333.

${ }^{77}$ Pinto, “The Libraries," p. 224, Green, “The History,” p. 459 and see also Mackensen, "Four," p. 297: it is furthered elaborated that Niebuhr, in 1750, found and copied an inscription on the wall of the kitchen of the Mustansiriyya, which said that the college was completed in 630 (1232-33 A.D.).

${ }^{78}$ Shalaby, History, p. 102.

${ }^{79}$ Imamuddin, Some, p. 28.

${ }^{80}$ Shalaby, History, p. 103. 
popularity in his time. This library was rich and was among those highly spoken of by historians and geographers like Ibn al-Athir and Maqdisi, etc. ${ }^{81}$ It is reported that al-Fậil received 120.000 copies of the collection of the Fạtimid imperial library which had just been conquered by alAyyūbi. ${ }^{82}$

Moving to the medieval era, we note the lament of AlQalqashandi (d. 1418): today kings take little interest in libraries; they are satisfied with madrasa libraries. Medieval Arab libraries were also attached to new madrasa. The Merinids built at least seven madrasas in Fez and other places, while the Hafșids constructed eight madrasas in Tunis, including four during 1236-1300. Al-Maqrizi (d. 1442) counted seventy-three madrasas in Cairo alone including the great Tomb-Madrasa of Sultān Hasan (d. 1361). The Mamlūk sultāns also built madrasas in Palestine and Syria, including the Zāhiriyya in Damascus ca. $1366{ }^{83}$ Besides these, there were three Egyptian madrasa libraries that will be discussed for current purposes, firstly the Madrasa al-Mahmüdiyya, which refers to the name of Jamāl al-Din Maḥmūd b. 'Ali al-Istadar (d. 799/ 1396). It was founded by him just two years before his death. It is mentioned that it was equipped with a big and excellent library, which is reported to have become the best library in Egypt and Syria in the time of al-Maqrizi at the beginning of the ninth century A.H. Secondly, there was also the madrasa which used the name of al-Jamaliyya, which was enriched by a good library. The last, the Madrasa al-Ashrafiyya, which also was located in Cairo, was derived from the name of Sultān al-Ashraf Sha'bān b. Husayn b. Qalāwūn (d. 778/1376). It was attached to a distinguished library used by the students of the madrasa. ${ }^{84}$

Facing the age of economic-cultural inertia vis-à-vis Europe, the development of Muslim libraries gives a gloomy picture. This can be seen from the small number of Muslim libraries, particularly libraries of rulers and scholars. Despite this, we will take a brief look at a number of libraries, which can be used as indicators of the existence

\footnotetext{
${ }^{81}$ Khalifa, Al-Kutub, p. 335-336, Green, “The History,” p. 459 and see also Pinto, “The Libraries," p. 225 and see also Meho, Libraries, p. 2.

${ }^{82}$ Imamuddin, Some, p. 36.

${ }^{83}$ Green, "The History," p. 460.

${ }^{84}$ Khalifa, Al-Kutub, p. 337-338.
} 
of madrasa libraries. This being the case, we note the report that in 1866 the Madrasa Där al-Ulum of Deoband was established by leading Muslim 'ulāmā. It is situated in the heart of the town of Deoband and is a part of the madrasa complex. The establishment of the library was initiated when the madrasa opened. It is spacious and has enough space for readers and stacks. The library is open for seven hours a day, simultaneously with the madrasa timings. Its collection includes 133,070 including books, journals, and manuscripts in 16 languages. ${ }^{85}$

Besides this, Nadvi reveals tens of libraries in the time of Muslim rule in India, including libraries of rulers, private individuals and madrasa. Among the madrasa libraries is Madrasa Faiz, which was founded in Nahar Vala Patan, Gujarat, in 1092 A.H. Next to the madrasa a mosque was constructed, in which rare books and a large number of manuscripts were found by Nadvi in 1931 A.D. There was also a big madrasa associated with the mosque, which stands near Talia Mal in Ahmedabad. Maulānā Imadudin was its Nä̌rim. Attached to this madrasa was a large library, which contained books on every subject, and many of these books were the best available on the subject. ${ }^{86}$ In line with this matter, he makes further note of other madrasa libraries such as Madrasa Qāại Shahāb al-Din Daulatābādi, Madrasa ĀAli, and Madrasa Mulla Shams al-Din. All these institutions had their own buildings, with residences (hostels) for the pupils, along with mosques and libraries. ${ }^{87}$

\section{Libraries of Scholars}

I have mentioned above that almost all Muslim libraries in the history of Islamic civilization have been open to the public. In the case of libraries of scholars, therefore, we find that they often issued invitations to other scholars to come to them, and were even open to society as a whole, such as the case with the libraries of a modest schoolmaster Muhammad Ibn Hazm. He was infinitely generous towards the public and freely permitted many scholars of Cordova to

${ }^{85}$ Taher, "Madrasa Libraries in India" in International Library Review, Vol. 21 (1989: 83-97), p. 85-86.

${ }^{86}$ Nadvi, "Libraries During the Muslim Rule in India" in Islamic Culture, Vol. 19 (1945: 329-347), p. 343-344 and see also Green, “The History,” p. 462.

${ }^{87}$ Ibid., p. $14-15$. 
work in his library and many other private libraries. ${ }^{88} \mathrm{I}$ shall base my examination of this type on Hodgson's framework of Arab-Islamic history, and my earlier observation that the flourishing growth of Muslim libraries had largely taken place in the second and third phases mentioned above. The second phase occurred in the transitional century and the third continued up to the commencement of the medieval era of Arab-Islamic society. With regard to this concept, it is narrated that 'Umar al-Wáqidi (736-811 A.D.) housed one hundred and twenty camels-load of books ${ }^{89}$ or 600 bookcases, each case requiring two men to carry it. ${ }^{90}$

In this time, Baghdad was the centre for cultural and intellectual activities, which enable people to have easy access to education. Ibn Hanbal's library amounted to twelve and a half camel loads, while that of his contemporary Yahyā b. Ma in (d. 233/847) filled 114 bookcases and four large jars. ${ }^{91}$ As a result, Baghdad had 36 libraries, of which one of the finest collections was that of al-Bayqāni (1033 A.D.). In Küfa, the library of Sufyān al-Thawrì is believed to have been a big private library developed by his owner, Abū 'Abd Allāh Sufyān b. Sa’̄id b. Rābigh al-Thawrì (161 A.H./778 A.D.). This person was a narrator of the prophetic traditions and jurisprudence. ${ }^{92}$ Dja far b. Muḥammad b. Hamdān (d. 323 A.H.) of al-Mawșil established an educational institution in his town with a rich library. Admission was granted to every one, and poor students were financially supported. Ja'far himself used to sit to teach in it and read from his own works. ${ }^{93}$ Another source states that this library was called Där al- $\mathrm{Tlm}$, and that its collection was established as a waqf for the use of seekers of

${ }^{88}$ Pinto, “The Libraries," p. 233 and see also 'Awwād, Khaqa'in al-Kutub al-Qadima $\overline{f i}$ '-Iraq = Ancient Libraries of 'Traq: From the Earliest Times to the Year 1000 A.H. (1591 A.D.), (Baghdad: al-Ma'arif Printing Press, 1948), p. 205-207.

${ }^{89}$ Nakosteen, History, p. 69 and see also Diwan, "Muslim," p. 22.

${ }^{90}$ Kohlberg, A Medieval, p. 72.

${ }^{91}$ Ibid., p. 72.

${ }^{92}$ Khalifa, Al-Kutub, p. 274.

${ }^{93}$ Shalaby, History, p. 73. 
knowledge so that it may be kept open for the public. ${ }^{94}$

Al-Djāhiz (d. 255/868), the distinguished scholar, had a warrāq named 'Abd al-Wahhāb b. 'Īsā in his private library. ${ }^{95}$ He lived in Basra from about 773 to 869 and was a brilliant man of letters, and a leading scholar of his age. ${ }^{96} \mathrm{He}$ was a real devourer of books, for in addition to his eagerness in reading and absorbing the books which he could buy, he took on deposit, as agent, books from booksellers, and no book ever fell into his hands but he read it from cover to cover, and even the books which he loved were the cause of his death as it was his habit to heap up round him all the books which he needed for his studies, and being on account of his great age partially paralysed. One day a heap of books fell on him and killed him. ${ }^{97}$ The other big private library was that belonging to al-Ṣahịb al-'Abbād (b. 326/938) who was very fond of learning. He therefore approached scholars and employed them in his library. It is said that the collection of the library contained more than four hundred camel-loads, ${ }^{98}$ which later became the reason why the owner refused an attractive appointment offered by the Chancellor Nūh b. Manșūr, for such a number was difficult to transport to the place. $^{99}$

After the conquest of Fa'timid caliphate, the library of 'Imād alDin al-Iṣfahāni contained some books of the library of the Fạtimids and some of the royal library from the time of Salāh al-Din al-Ayyūbi. Al-Ișfahāni was a historian, and had a close relation with the government of al-Ayyübi. ${ }^{100}$ Having heard of the low prices at which the valuable Fạtimid books were estimated, 'Imād al-Din al-Iṣfahāni hurried to the spot and took part in the auction. The wonderful collections he chose for himself cost some hundreds of dinārs, but al-Ayyūbi did not let

${ }^{94}$ Makdisi, The Rise of Colleges: Institutions of Learning in Islam and the West, (Edinburgh: Edinburgh University Press, 1981), p. 26.

${ }^{95}$ Shalaby, History, p. 90 and see also Green, “The History," p. 459.

${ }^{96} \mathrm{Ibn}$ al-Nadim, The Fibrist, Vol. 2, p. 1022.

${ }^{97}$ Pinto, “The Libraries," p. 215.

${ }^{98}$ Khalifa, Al-Kutub, p. 271.

${ }^{99}$ Shalaby, History, p. 77 and see also Nakosteen, History, p. 69.

${ }^{100}$ Khalifa, Al-Kutub, p. 273-274. 
him pay anything and made him a present of them. Shortly afterwards al-Ayyūbi bestowed another set of books on 'Imād al-Din, selected from the Palace Library.'101

Among the private libraries of Cordova, the library of Ibn Futays was ranked as the biggest and the most beautiful. It was built in such an ingenious way that all the bookshelves could be seen from one point. This library employed some people including Abū 'Abd Allāh al-Hadrāmi (d. 396/1005-6), a Cordovan scholar, as librarian, and there were also six other copyists and calligraphists on fixed salaries. ${ }^{102}$ Another place in which books were accorded a similar respect was the library of al-Qāại Abū al-Mutrif, a Cordovan judge, containing mostly rare books and masterpieces of calligraphy, and employing six copyists in fulltime employment. He was a great book-lover. ${ }^{103}$ It is recorded that he had six transcribers in his library, to each of whom a regular salary was assigned. He used to try to buy all new books and, in case this could not be done, a copy was to be made. ${ }^{104}$ This library was sold at auction for 40,000 dinärs after his death in 1011. ${ }^{105}$

In 1139 A.D. there was a library belonging to the poet-physician al-Mu'arrif, who wrote a commentary on Aristotle. According to Ibn Abi Usaybi'a, this library contained thousands of books on every branch of learning including medical and scientific works, ${ }^{106}$ which were accompanied by copious notes bearing the contents and the name of Mu'arrif. Ibn Abi Usaybi'a also describes a library of the physician Ibn al-Mutrān, with holdings of more than 3000 volumes. There were three copyists working constantly in his service, and he himself performed the calligraphy in numerous books. After his death in 578/ 1191, this exceptional collection was sold to 'Imrān who was also a bibliophile physician. ${ }^{107}$ Another private collection that faced a very different fate was the library of al-Mubashshir b. Fātik. After his death,

\footnotetext{
${ }^{101}$ Shalaby, History, p. 110.

${ }^{102}$ Imamuddin, "Hispano-Arab," p. 107.

${ }^{103}$ Nakosteen, History, p. 71.

${ }^{104}$ Shalaby, History, p. $91-92$.

${ }^{105}$ Nakosteen, History, p. 71.

${ }^{106}$ Merlet, "Islamic," p. 134.

${ }^{107}$ Micheau, “The Scientific,” p. 988.
} 
all his collection was thrown away into a basin by his wife who was angry because she felt neglected by him, for his attention was always on his books. ${ }^{108}$

\section{University Libraries}

Referring once again to the chronological history of Arab-Islamic society as proposed by Marshall Hodgson and accepted via Green in his approach known as the Diffusionist Model, we are going to skip here four time periods, starting from the age of traditional Arab culture to the medieval era of regional Arab-Islamic societies in the late sixteenth century. The reason for this decision is the emergence of university libraries commencing in the age of economic-cultural inertia vis-à-vis Europe. ${ }^{109}$ Some argue that Muslim universities commenced with the establishment of the Bayt al- $\mathrm{Im}$ (988 AD) as the secular university in Egypt. Others are of the opinion that such educational activities were merely centres of learning, which provided opportunities for study, and were not the same as the university in the sense in which we understand it. ${ }^{110}$

The second of these opinions will form the basis for our approach to this type. Therefore, our discussion focuses on the period of cultural inertia in relation to Europe, following the evolution of advanced Islamic education by the tenth century A.H., and the adaptation of mosque teaching to the sectarian outlook of certain regimes, in which formal universities which originated from some mosques provided salaries for the scholars who taught lessons organised by a certain curriculum. The students who completed the courses given would receive certificates of degrees. The important relevance to this topic is that these universities were attached to libraries, and these can be seen in the university of al-Azhār in Cairo, of al-Zaytunā in Tunis, and of al-Qarawiyyin in Fez.

${ }^{108}$ Micheau, “The Scientific,” p. 988.

${ }^{109}$ See, "Djāmi'a" in The Encyclopaedia of Islam.

${ }^{110}$ Macmillen, "Egyptian University Libraries" in Michael Wise and Anthony Olden (Comp. and edit.), Information and Libraries in the Arab World, (London: n.n.,1994), p. 81. 
The mosque of al-Azhār in Cairo, founded by Djawhar, the general of the Fạtimid ruler Mu'iz li-Din Allāh (r. 341/953 $3^{111}$ ), whereby some sources say that al-Azhār university is the oldest university in the world. ${ }^{112}$ The date of its establishment takes us back to the very foundation of the city itself in which it stands in 970 A.D. It has braved the storms of a millennium, and is to this day regarded by the followers of the prophet as the truest defender of Muslim tradition, the proven guide along the tortuous paths of religion and jurisprudence of the faithful. ${ }^{113}$ Al-Azhār University library survived the ravages of time and its rich collection still reminds one of the glorious days and the love of learning and literature of the Fatimids. ${ }^{114}$

Another university library was that established by Ahmad Bey (1837-1855) at the Zaytunā Mosque-University, which he endowed with a large new library called the Ahmadiyya collection. Even in such remote areas as Jaghbub in south-eastern Libya and Tamghrut in southern Morocco, the Sanüsiyya and Nassiriyya neo-orthodox mystical orders built education-oriented complexes possessing noteworthy libraries. ${ }^{115}$ The establishment of university libraries was a significant channel in the development and foundation of human civilization and progress. Therefore, many universities accompanied by libraries were established in the Islamic world, including such western universities as the American University in Beirut in 1864 and Robert College in Istanbul in $1863 .{ }^{116}$

In 1897, the separate collections of al-Azhār University's riwāq were consolidated into a central library that by the 1930s was supervised by a graduate of the University of London's School of Librarianship. ${ }^{117}$ In this regard, Arab countries with few or no national universities quickly expanded their systems of higher education. The

111“"Mu'izz" in The Encyclopaedia of Islam, Leiden: Brill, 1960.

${ }^{112}$ Francis, Libraries and Information in the Middle East (London: British Library, Research and Development Department, 1993), p. 35.

${ }^{113}$ Heidborn, "A Muslim University" in The Imperial and Asiatic Quarterly Review and Oriental and Colonial Record, Vol. 16 (July-October 1903: 300-326), p. 300.

${ }^{114}$ Imamuddin, Some, p. 37.

${ }^{115}$ Green, “The History,” p. 462.

${ }^{116}$ Ibid., p. 462.

${ }^{117}$ Ibid., p. 464. 
oldest academic library in Syria is at Damascus University, which was founded in 1919, and played a prominent part in the maintenance of Syrian identity during the French occupation between the two world wars. The library of this university contains about 250.000 volumes in a central library and several branches. ${ }^{118} \mathrm{~A}$ few decades later, this country saw the opening of Aleppo University in 1946. Egypt built new universities in Asyut in 1949, Heliopolis or 'Ayn Shams in 1950, and Manșūra in1972. It also transformed al-Azhār into a modern university, leaving the old mosque-related facility as a school of theology with its own library. ${ }^{119}$

Lebanon saw the creation of the Lebanese University in Beirut in 1951 and the Arab University of Beirut in 1960. The second one has the strongest library in Lebanon containing 200.000 volumes and receiving 3.500 periodicals. ${ }^{120}$ Iraq established the University of Baghdad in 1957, al-Mustanșiriyya University in Baghdad in 1963, and the University of Mawșul in 1967. Jordan founded the University of Jordan in Amman, 1962 and then Yarmuk University in Irbid in 1976. Sudan transformed Gordon Memorial College into the University of Khartoum (early 1950s) and created Umdurman Islamic University in 1965. In Libya, Gar Younis University in Ben Ghazi was set up by 1955 by King Idris, while the republican government of Colonel Mu'ammar Ghaddāfi founded al-Fatāḥ University (Tripoli, 1973). ${ }^{121}$ In this period of development, Egypt is said to maintain leadership in terms of its library, but even its collections were too small to meet the needs of the university. The largest library at the University of Cairo was over 200.000 volumes, but these had to meet the needs of over 50.000 students. $^{122}$

The University of Mohammed V founded in Rabat in 1957 was the first modern university in Morocco to include a library. AlQarawiyyin, with its traditional library, remained as a school of theology

\footnotetext{
${ }^{118}$ Francis, Libraries, p. 84.

${ }^{119}$ Green, “The History,” p. 466.

${ }^{120}$ Francis, Libraries, p. 64.

${ }^{121}$ Green, “The History,” p. 466.

${ }^{122}$ Chandler, Libraries in the East: An International and Comparative Study, (London: Seminar Press, 1971), p. 36-37.
} 
in the modern system of higher education. The University of Tunis was opened in 1958, but al-Zaytunā was closed and its books transferred to the new national library. In 1961 Algeria indigenised the University of Algiers and set up new universities in Constantine and Oran. Saudi Arabia founded King Saudi University in Riyadh, 1957 and the Islamic University in Medina, 1961. Kuwait University dates from 1966, and the University College of Bahrain was established in $1978 .{ }^{123}$

Al-Azhär University is one of the oldest academic institutions in Egypt, founded in the $4^{\text {th }} / 9^{\text {th }}$ century. ${ }^{124}$ Its library collection was very rich in old Arabic manuscripts and Arabic classics on religious and historical subjects. It has a collection of 80.000 volumes, including 20.000 manuscripts. Cairo University, which was founded in 1908, has a collection of about 1.000 .000 volumes, and 7.000 periodicals. Alexandria University, which was established in 1942, owns a central library with a collection of 122.225 volumes, and eight college libraries with a total collection of over 1.000 .000 volumes. In Iraq, the central library of the University of Baghdad was established in 1959, and has developed rapidly since then. It has a collection of 204.000 volumes, 1950 periodicals, 10.190 maps, and a number of phonorecords, manuscripts, and microfilms. ${ }^{125}$

\section{Some Notes on the Collapse of Muslim Libraries}

Here I attempt to address the decline of Muslim libraries by referring to Hodgson's framework of the historical periods of ArabIslamic society discussed below. This is a reasonable strategy for exploring the gloomy phases of the history of Islamic libraries. Based on my findings from several different sources, this unexpected period appears notably since the middle of the classical age of cosmopolitan Arab-Islamic culture. This murky era for Islamic libraries is rooted in different circumstances causing decline, which can be used to throw a light on the internal and external factors behind this situation.

\footnotetext{
${ }^{123}$ Green, “The History,” p. 466.

${ }^{124}$ See "al-Azhār" in The Encyclopaedia of Islam.

${ }^{125}$ Kindilchie, "Libraries in Iraq and Egypt: A Comparative Study" in International Library Review, Vol. 9 (1997: 113-123), p. 116.
} 
The issue of the decline of Muslim libraries has been much connected with internal factors, which may be accounted for historically from different sources. In this connection, the platform of political conflicts and sectarian propaganda had great influence on the destiny of Muslim libraries. In such circumstances, the destruction and burning of books considered as heretical by the holders of power occurred as daily activities, without feeling of reservation based on intellectual principles. At the time of the conquest of Rayy by Mahmud b. Ghazna in 420/1029, this sultān is said to have fought against all forms of heterodoxy such as the doctrine of the Mu'tazilites and burned their books, as well as those of the philosophers and astronomers that he found in the library founded by a Buwayhid Amir. ${ }^{126}$

Yaqūt asserts that a lot of books were burned in 1055 A.D. when Tughril Beg, the Seljuk, entered the city of the Abbasids. ${ }^{127}$ The vizier, Bahä' al-Dawla had a library containing more than 100,000 volumes and this library was destroyed by fire during Tughril Beg's march on Baghdad in 451/1059. ${ }^{128}$ Such descriptions have coloured the fate of many Muslim libraries. Whenever orthodoxy prevailed and the heretics were under suspicion, their books were destroyed, and when schismatics were in power, they suppressed the writings of their opponents. ${ }^{129}$ Consequentially, the destruction of sectarian libraries by traditionalists and enthusiasts supporting the continuance of Islam in its pristine purity proved catastrophic for the community. ${ }^{130}$

In 461/1068-69 all libraries in Egypt except for the private library of the inner palace were completely destroyed during the famine and reign of terror caused by a failure of the Nile and the struggles between the Turkish troops and the black Sudanese regiments. ${ }^{131}$ An eyewitness has stated that he saw twenty-five camel-loads of books taken by one

\footnotetext{
${ }^{126}$ Micheau, “The Scientific,” p. 990.

${ }^{127}$ Mackensen, "Four," p. 288-289.

${ }^{128}$ Kohlberg, A Medieval, p. 72.

${ }^{129}$ Bashiruddin, “The Fate,” p. 154-155.

${ }^{130}$ Ibid. p. 161.

${ }^{131}$ Mackensen, "Moslem Libraries and Sectarian Propaganda" in The American Journal of Semitic Languages and Literatures, Vol. 51 (October 1934-July 1935: 83-113),
} p. 97. 
creditor alone. ${ }^{132}$ Beautiful bindings were used for making shoes for soldiers. Parts of the leaves were burned and others were thrown into the Nile, which in turn resulted in the end of the Fatimid royal library. Another famous Fatimid library which suffered in the catastrophe of 1068 was the one attached to the Där al-Tlm or Där al-Hikma founded in 1005 by the Caliph al-Hākim, known as one of the strangest figures in all Muslim history. ${ }^{133}$ Another source records that the decline of the Fătimid caliphate coincided with the power of al-Ayyübi in 567/1171, and the institutes of the Shi'a and their libraries containing valuable books were taken off and in some cases burnt. ${ }^{134}$

After the death of al-Hakam II, the regency came under Manșūr b. Abi 'Ammār, and the liberal policy of al-Hakam II was abandoned and that of oppression and repression adopted. Books dealing with natural philosophy, astronomy, or the doctrine of the ancients were given away or destroyed and the only ones allowed remaining were those dealing with rhetoric, grammar, poetry, history, law, and tradition. Every now and then masters were changed and fire and sword worked havoc without end. In one of these civil wars books suffered most. They were either destroyed or sold at low prices and most of the literary treasures which the royal library contained were scattered through Spain, says the historian Said; some were taken to Seville, some to Granada, some to Almeira and other principle cities. ${ }^{135}$ The library of Cordova also perished miserably. ${ }^{136}$

Apart from these incidents of book destruction because of political quarrels and sectarian propaganda, it cannot be doubted that a large number of books were lost through carelessness, neglect, and ignorance. ${ }^{137}$ Thus, the arrangement and placement of different books were not handled by people who had a sense of respect for the historical and intellectual works. The lifespans of wonderful libraries were not so long due to the carelessness of the librarians as well as the changes

\footnotetext{
${ }^{132}$ Imamuddin, Some, p. 36.

${ }^{133}$ Bashiruddin, “The Fate," p. 157-158.

${ }^{134}$ Pedersen, "Some," p. 531.

${ }^{135}$ Bukhsh, “The Islamic," p. 130.

${ }^{136}$ Pinto, "The Libraries," p. 238.

${ }^{137}$ Sibai, Mosque, p. 119.
} 
of government and acts of vandalism by conquerors, who tried to eradicate everything they found made by the hands of the defeated, and so these immense intellectual riches gradually vanished. In Arabic history, notices of the loss of this or that library are not infrequent. ${ }^{138}$

External factors can also be connected to the decline of the Arab-Islamic libraries. One may conclude that the end of the classical era was marked by library-destroying foreign conquests; the Crusaders (ca. 1100 onward) ${ }^{139}$ and then especially the Mongols and Tartars in the East. According to the Egyptian scholar Ahmad b. 'AГi alQalqashandi (d. 821/1418), the library of the Abbasids was destroyed under (Hulagu Khan 656/1258 $\left.{ }^{140}\right) \cdot{ }^{141}$ In Spain, the reconquista (ca. 1065 onward) gradually eliminated the Muslim polity of that land. IntraIslamic rivalries also prove disruptive; we have already mentioned that Cordova's great library was first thinned out by Muslim dogmatics attacking secularism/heresy, and then dispersed in the late eleventh century by invading Moroccan sectarians. The Sunni champion alAyyübi, who built many new madrasas, nevertheless suppressed the Shi' Da a al-Tlm upon the seizure of Cairo in 1171. This act may have spawned the myth, which first entered the literary record about this time, that the Muslims had destroyed the Serapium. ${ }^{142}$

Muslim libraries grew out of the interests and needs of cultivated individuals, literary societies, and in contexts of learning. In turn they suffered various fates. Many private as well as public collections were destroyed or scattered by hordes of ignorant invaders. Berbers did the same thing in the West. Christians were also responsible for the destruction of some of the libraries belonging to their Muslim neighbours. Cardinal Ximenez, complaining of the interest Spanish Christians showed in Muslim books to the exclusion of their own sacred writing, burned eighty thousand volumes in the public square at Granada. ${ }^{143}$ The Crusaders are said to have destroyed the great library

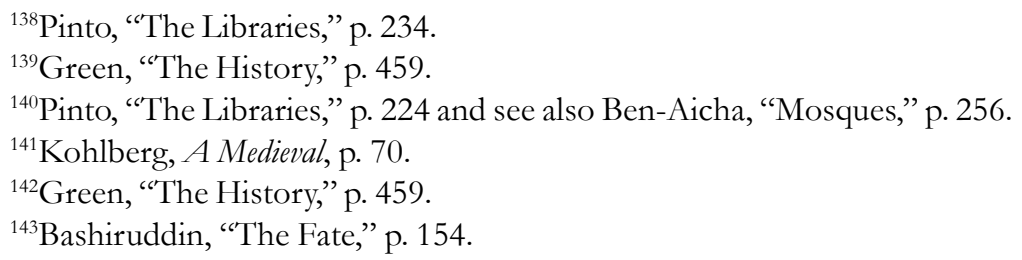


at Tripoli in Syria and probably committed other similar offences. ${ }^{144}$ In the long history of Islamic rulers, particularly in Spain in which Islam gradually lost political power and in which Muslim cities fell into Christian hands, the Muslims receded more and more to the South till they finally took refuge in Granada. But with the fall of their last stronghold, Granada, also their life and property, in fact everything they possessed, their language, literature and culture were all left at the mercy of the victorious Christians who did not prove tolerant towards their Muslim subjects. Muslim schools were closed, libraries were burnt down and repressive laws were passed to compel them to renounce the Arabic language. ${ }^{145}$

Besides the native and foreign interference of this gloomy time, many of the mosque-universities, madrasas, and palace libraries suffered from natural disasters. ${ }^{146}$ Natural disasters can also be blamed for the destruction of some book collections. Many such incidents causing damage to libraries are reported. In 131/748, Damascus was jolted by a quake, which caused portions of the mosque's ceiling to collapse. Another quake that occurred in 233/847 resulted in extensive damage including the fall of the main minaret. Over again, in 552/1157, 597/ 1200 , and $598 / 1201$, the Umayyad was badly damaged by earthquakes some of which caused loss of life the worshipers. ${ }^{147}$

\section{E. Conclusion}

Muslim libraries have been one of the important aspects of Islamic civilization, and are a proper domain for intellectual research. Nevertheless, this issue has been marginalized in the field of Islamic studies, and appears to have been an unimportant phenomenon among scholars, particularly Muslim scholars. It is my observation that this may be due to the fact that accounts of Islamic libraries are mostly exaggerated and display many contradicting reports concerning the same

\footnotetext{
${ }^{144}$ Mackensen, “Moslem,” p. 83-84 and see also Nakosteen, History, p. 71-72.

${ }^{145}$ Imamuddin, "Hispano-Arab," p. 114.

${ }^{146}$ Green, “The History,” p. 461.

${ }^{147}$ Sibai, Mosque, p. 123 and see also Massignon, "Etude sur les manuscrits des bibliotheques de Bagdad (Mission de 1908)" in Revue du Monde Musulman 8, 1909,
} p. 223. 
issues. Given this state of affairs, it seems to me that this area should be explored further in an academic way. In doing so, the work of Van Koningsveld, "Greek Manuscripts in the Early Abbasid Empire..." is an extremely important reference because it tries to give a critical analysis of the different sources that constitute the main sources of information concerning the library of Bayt al-Hikma. This kind of study is fruitful in that it produces a clear definition of the fiction and the fact of the historical records around Muslim libraries. Therefore, further studies on this topic will be more interesting if they can be focused on the historical approaches manifested in the accounts and their character as fiction and fact.

Apart from the above, this study is trying to obtain a comprehensive understanding of the complexity of the typology of the Muslim libraries in the world, and follows a framework made up of five types of Islamic libraries based on the ownership and supervision by persons and institutions. Mosque libraries are proposed as the first and oldest Muslim libraries because it is believed that mosques are the first institution of the Muslim community. Mosques have been used for different functions, particularly education. The activity of education then produces different works on Islamic matters, which are then placed in the mosques as public services. The libraries of rulers or ruling families are the second type, which had an influence on Muslim libraries for a long time. Every library found beneath a royal family is classified into this classification. As a result, libraries like those of Khālid b. Yazid as a prince, al-Ma'mūn as a caliph and Yahyāa al-Munadjdjim as a vizier fall into this type. The next one is the collections of madrasa (schools), which are represented here as madrasa libraries. Under this head are described different madrasas, all of which were accompanied by good libraries such as Madrasa Nižamiyyy and Madrasa Mustansiriyya. The fourth type is the libraries of scholars, and these constitute an interesting phenomenon in the Muslim world. Thus, collections located clearly as being under the responsibility or ownership of scholars are typified as the libraries of the scholar, no matter whether they are open to public or limited to certain groups or persons, for example 'Umar al-Wâqidi (736-811 A.D.) and al-Djāhiz (d. 255/868). The last kind of Muslim library is the university library, which is comprised of 
the collections of Islamic universities. This type displays examples such as the libraries of al-Azhār university in Cairo and of al-Zaytūnā in Tunis.

Other important issues are the origins, the development, and the destruction of the Muslim libraries. I have tried to explore the libraries mentioned here with reference to the circumstances of their establishment. Despite this, there is no clear evidence about the exact time of the emergence of Muslim libraries. What is recorded is the growth in intellectual activities starting from the very beginning of the Umayyad caliphate, represented in the library of Prince Khālid b. Yazid. From this time on, Islamic libraries continued to develop until the gloomy period at around the end of the classical era of Islamic society. Starting from this period, Muslim libraries have been facing different difficulties in their development, which this study has classified into internal and external aspects. The former is comprised of socio-political conflicts together with sectarian propaganda between Muslim rulers, which led to the burning of different collections in libraries and also the carelessness of the Muslims themselves towards the maintenance of their libraries. The latter is concerning the problems from outsiders such as the attacks from non-Muslim hands as well as natural disasters. 
Nurdin Laugu

\section{BIBLIOGRAPHY}

'Awwād, Kürkis, Khazà'in al-Kutub al-Qadima fì'-Irāq = Ancient Libraries of Iraq: From the Earliest Times to the Year 1000 A.H. (1591 A.D.), Baghdad: al-Ma'arif Printing Press, 1948.

Bashiruddin, S., "The Fate of Sectarian Libraries in Medieval Islam" in Libri: International Library Review, Vol. 17 (1967: 149-162).

Ben-Aicha, Hedi, "Mosques as Libraries in Islamic Civilization, 7001400 A.D." in The Journal of Library History, Vol. 21, No. 2 (Spring 1986: 253-260).

Benjelloun-Laroui, Latifa, Les Bibliotheques an Maroc, Paris: G.-P. Maisonneuve et Larose, 1990.

Binebine, Ahmed-Chouqui, Histoire des Bibliotheques an Maroc, Rabat: Universite Mohammed V, 1992.

Bukhsh, Khuda, "The Islamic Libraries" in The Nineteenth Century and After, Vol. 52 (July-December 1902: 125-139).

Chandler, George, Libraries in the East: An International and Comparative Study, London: Seminar Press, 1971.

Dāwūdi, Muhammad al-, Al-Masjid fi'l-Kitāb wa'l-Sunna wa'-Aqwāl alUlamä, n.p.: Dār al-Wafa, n.d.

Daywahḥi, Sa`id al-, Bayt al-Hikema, Al-Mawșil: Mu'assasat Dār al-Kutub li'l-Ṭibā'a, 1972.

Diwan, Muhammad Rustam Ali, "Muslim Contribution to Libraries During the Medieval Times" in Islam and the Modern Age: A Quarterly Journal, Vol. 9 No. 2 (May 1978: 19-34).

Diyāb, Hamid al-Shafīi, Al-Kutub wa'l Maktaba fìl Andalus, al-Qāhira: Dār Qibā' li'l- Tịāà wa'l-Nashr wa'l-Tawzi', 1998.

Eche, Youssef, Les bibliotheques arabes publiques et semi-publiques en Mesopotamie en Syrie et en Egypte au Moyen Age, Damas: Institut Francais de Damas, 1967.

The Encyclopaedia of Islam, WebCD Edition, Leiden: Brill Academic Publishers, 2003. 
Francis, Simon, Libraries and Information in the Middle East, London: British Library, Research and Development Department, 1993.

Green, Arnold H., "The History of Libraries in the Arab World: A Diffusionist Model" in Libraries and Culrure, 23 (4), (Fall 1988: 454-473).

Harvey, John F. and Shahr Azar Musavi, "Tehran Mosque Libraries and a Comparison with American Christian Church Libraries" in International Library Review, Vol. 13 (1981: 385-395).

Hamāda, Muhammad Māhir, Al-Maktabāt fi'l-Islām: Nash'atubā wa Tatammurubā wa Mașa'irubā, Bayrūt: Mu'assasat al-Risāla, 1981.

Heidborn, Adolf, "A Muslim University" in The Imperial and Asiatic Quarterly Review and Oriental and Colonial Record, Vol. 16 (JulyOctober 1903: 300-326).

Hulūdji, 'Abd al-Sattār al-, Al-Kutub wa'l-Maktabāt al-'Arabiyya Bayn alQadim wall-Hadith, al-Qāhira: al-Dār al-Miṣriyyat al-Lubnāniyya, 2002.

Ibn Khallikan, Biographical Dictionary, transl. from the Arabic by Mac Guckin de Slane, Vol. 3, Paris: Oriental Translation Fund, 1871. Ibn al-Nadim, The Fibrist of al-Nadim: A Tenth-Century Survey of Muslim Culture, transl. And ed. by Bayard Dodge, 2 Vols., New york: Columbia University Press, 1970.

Imamuddin, S.M., "Hispano-Arab Libraries, Books and Manuscripts: Muslim Libraries and Bookmen in Spain" in Journal of the Pakistan Historical Society, Vol. 52, Part 1 (January 1959: 101-119).

Imamuddin, S.M., Some Leading Libraries of the World, Dhaka: Islamic Foundation, 1983.

Ivanow, W., "A Notice on the Library Attached to the Shrine of Imam Riza at Meshed" in The Journal of the Royal Asiatic Society of Great Britain and Ireland, (1920: 535-563).

Jones, John Winter, The Travels of Ludovico Di Varthema in Egypt, Syria, Arabia Deserta and Arabia Felix, in Persia, India, and Ethiopia, A.D. 1503 to 1508, London: Printed for the Hakluyt Society, 1863.

Kabir, Mafizulla, "Libraries and Academies During the Buwayhid Period 946 A.D. to 1055 A.D.” in Islamic Culture, Vol. 33 (1959). 
Khalifa, Sha'bān 'Abd al-'Ażiz, Al-Kutub wa'l-Maktabat fi'l- 'Usür al-Wustā, Cairo: Dār al-Miṣriyya al-Lubnāniyya, 1997.

Khalifa, Sha'bān 'Abd al-'Aziz, Maktabat al-Iskandariyyat al-Qadima wa Mashrū' Ibyāìhā fi'l-Waqt al-Hạdịir, (al-Qāhira: al-Dār al-Mișriyyat al-Lubnāniyya, 2002.

Khurshid, Anis, "Growth of Libraries in India" in International Library Review, 4 (1972: 21-65).

Kindilchie, Amer Ibrahim al-, "Libraries in Iraq and Egypt: A Comparative Study" in International Library Review, Vol. 9 (1997: 113-123).

Kindilchie, Amer Ibrahim al-, "Libraries in Iraq: A Short Report" in Michael Wise and Anthony Olden (Comp. and edit.), Information and Libraries in the Arab World, London: n.n., 1994.

Kohlberg, Etan, A Medieval Muslim Scholar at Work: Ibn Tâawus and His Library, Leiden: E.J. Brill, 1992.

Mackensen, Ruth Stellhorn, "Arabic Books and Libraries in the Umaiyad Period" in The American Journal of Semitic Languages and Literatures, Vol. 52 (October 1935-July 1936: 245-253), Vol. 53 (October 1936-July 1937: 239-250), Vol. 54 (October 1937: 41-61), Vol. 56 (January-October 1939: 149-157).

Mackensen, Ruth Sellhorn, "Background of the History of Muslim Libraries" in The American Journal of Semitic Languages and Literatures, Vol. 51 (October 1934-July 1935: 114-125), Vol. 52 (October 1935-July 1936: 22-33, 104-110).

Mackensen, Ruth Stellhorn, "Four Great Libraries of Medieval Baghdad" in The Library Quarterly, Vol. 2, No. 3 (July 1932: 279299).

Mackensen, Ruth Stellhorn, "Moslem Libraries and Sectarian Propaganda" in The American Journal of Semitic Languages and Literatures, Vol. 51 (October 1934-July 1935: 83-113).

Macmillen, Sandy, "Egyptian University Libraries" in Michael Wise and Anthony Olden (Comp. and edit.), Information and Libraries in the Arab World (London: n.n., 1994). 
Makdisi, George, The Rise of Colleges: Institutions of Learning in Islam and the West, Edinburgh: Edinburgh University Press, 1981.

Makkāri, Ahmed Ibn Mohammed al-, The History of the Mohammedan Dynasties in Spain, Transl. and illustrated with critical notes by Pascual de Gayangos, London: Oriental Translation Fund, [Vols. 1, 1840; Vol. 2, 1843].

Massignon, Louis, "Etude sur les manuscrits des bibliotheques de Bagdad (Mission de 1908)" in Revue du Monde Musulman 8 (1909: 223-227).

Meho, Lokman I. and Mona A. Nsouli, Libraries and Information in the Arab World: An Annotated Bibliography, London: Greenwood Press, 1999.

Merlet, Shukrieh R, "Islamic Libraries of the Middle East" in Libri, Vol. 39, No. 2 (1989: 127-140).

Meyerhof, Max, "On the Transmission of Greek and Indian Science to the Arabs" in Islamic Culture, Vol. 11 (1937: 18-29).

Micheau, Francoise, "The Scientific Institutions in the Medieval Near East" in Encyclopedia of the History of Arabic Science, Vol. 3 (1996: 985-1007).

Nadvi, S. A. Zafar, "Libraries During the Muslim Rule in India" in Islamic Culture, Vol. 19 (1945: 329-347), Vol. 20 (January 1946: 3-20).

Nakosteen, Mehdi, History of Islamic Origins of Western Education A.D. 800-1350: With an Introduction to Medieval Muslim Education, Colorado: University of Colorado Press, 1964.

Nashshār, al-Sayyid al-Sayyid al-, Tärikeh al-Makatabät fi Mișra: al-'Assr al-Mamlūki, Cairo: al-Dār al-Miṣriyyat al-Lubnāniyya, 1993.

Nicholson, Reynold A, A Literary History of the Arabs, London: T. Fisher Unwin, 1907.

Pedersen, Johs, "Some Aspects of the History of the Madrasa" in Islamic Culture, Vol. 3 (1929: 525-537).

Pinto, Olga, "The Libraries of the Arabs During the Time of the Abbasides" in Islamic Culture, Vol. 3 (1929: 210-243). 
Prince, Chris, "The Historical Context of Arabic Translation, Learning, and the Libraries of Medieval Andalusia" in Library History, Vol. 18 (July 2002: 73-87).

Rasdi, Mohamad Tajuddin Haji, The Mosque as a Community Development Centre: Programme and Architectural Design Guidelines for Contemporary Muslim Societies, Malaysia: Universitas Teknologi Malaysia, 1998.

Rau, R. Vasudeva, "Did Omar Destroy the Alexandrian Library?" in the Nineteenth Century, Vol. 36 (July-December 1894: 555-571).

Richardson, Ernest Cushing, The Beginnings of Libraries, London: Archon Books, 1963.

Riggs, Rev. Elias, "The Library of the Mosque of St. Sophia" in The Library Journal: Official Organ of the American Library Association, Vol. 10 (January-December 1885: 106).

Sāqāqi, Yahyā Maḥmūd, Al-Waqf wa Bunyat al-Maktabat al-Arabiyya: Istibtān li'-Mawrūth al-Thaqäfi, al-Riyạ̣̄: al-Mamlakat al-'Arabiyyat al-Su'ūdiyya, 1988.

Shadid, W.A. and P.S. van Koningsveld, Moslims in Nederland: Minderheden en religie in een multiculturele samenleving, Houten: Bohn Stafleu Van Loghum, 1997.

Shalaby, Aḥmad, History of Muslim Education, Beirut: Dar al-Kashshaf, 1954.

Sibai, Mohamed Makki, Mosque Libraries: An Historical Study, London: Mansell Publishing Limited, 1987.

Sibai, Mohamed Makki. 'Mosque Libraries' (Book Review) in The Journal of Library History. Vol. 8 (1988).

Spies-Aligarh, Von Otto, "Die Bibliotheken des Hidschas" in Zeitschrift der Deutschen Morgenl ndischen Gesellschaft, Vol. 90 (1936: 83-120).

Taher, Mohamed, Mohammed Burhanuddin and Amin Ahmed Khan, and G. Chandler (editor), "Madrasa Libraries in India" in International Library Review, Vol. 21 (1989: 83-97).

Taher, Mohamed, "Mosque Libraries: A Bibliographical Essay" in Library and Culture. Vol. 27 (1992). 
Van Koningsveld, P. S., “Naskah-Naskah Yunani Tentang Bait alHikmah dan Kebijakan Beragama Khalifah al-Makmum" in Herman Leonard Beck \& Nico Kaptein (eds.), Studi Belanda Kontemporer Tentang Islam: Lima Contoh, Jakarta: INIS, 1993.

Van Koningsveld, P. S., "Greek Manuscripts in the Early Abbasid Empire: Fiction and Facts about Their Origin, Translation and Destruction" in Bibliotheca Orientalis, Vol. 55 (Mey-August 1998: 345-372).

Wasserstein, D, The Library of al-Hakam II al-Mustansir and the Culture of Islamic Spain, Manuscripts of the Middle East, pp. 1-23. 